\title{
Is the Fama French Three-Factor Model Relevant? Evidence from Islamic Unit Trust Funds*
}

\author{
Shahrin Saaid Shaharuddin ${ }^{1}$, Wee-Yeap Lau ${ }^{2}$, Rubi Ahmad ${ }^{3}$
}

Received: April 7, 2018 Revised: October 1, 2018 Accepted: October 10, 2018

\begin{abstract}
The study tests the Fama and French three-factor model by using the newly created Islamic equity style indices. Based on a dataset from May 2006 to April 2011, the three-factor model is tested based on returns of Islamic unit trust funds using the Generalized Method of Moments (GMM) methodology. The sample period is also divided between periods before and after the Global Financial Crisis in August 2008 to test for robustness, and the Bai and Perron (2003) multiple structural break test was used to determine the structural break in the series. The analysis shows that the Fama and French model is valid for Islamic unit trust funds before and after the collapse of Lehman Brothers. The result further indicates the reversal of size effect. As for trading strategies, value funds outperform growth funds by annualized 3.13 percent for the full period. During pre-crisis period, value funds perform better than growth funds while in post-crisis, size factor yields better return than other strategies. As policy suggestion, fund managers need to be aware of the reversal of size effect, and they need to ensure a more transparent stock selection process so that investors can make an informed decision in their asset allocation.
\end{abstract}

Keywords: Unit Trust Funds, Equity Style, Fama and French, Islamic Finance.

JEL Classification Code: G11, G12, G14.

\section{Introduction}

Researchers in the area of asset pricing have long accepted the Fama and French three-factor model as an

* The earlier version of this paper was presented at the Malaysian Finance Association Conference 2016 and the 7th Islamic Banking, Accounting and Finance Conference 2016. The authors appreciate all comments from the discussants and session chair from the conference as well as the anonymous reviewers. The authors would like to thank the support by the UM-INCEIF Research [grant number MO006-2017].

1 First Author. Senior Lecturer, Department of Finance and Banking, Faculty of Business and Accountancy, University of Malaya, Malaysia, E-mail: shahrin@um.edu.my

2 Corresponding Author. Associate Professor, Department of Applied Statistics, Faculty of Economics and Administration, University of Malaya, Malaysia [Postal Address: Lembah Pantai, 50603 Kuala Lumpur, Malaysia] Tel: +(60) 379673747 ,

Fax: +(60) 37956 7252, E-mail: wylau@um.edu.my

3 Associate Professor, Department of Finance and Banking, Faculty of Business and Accountancy, University of Malaya, Malaysia, E-mail: rubi@um.edu.my improvement to the Capital Asset Pricing Model (CAPM) which was established by Sharpe (1964) and Lintner (1965). In fact, Fama and French's (1992) finding which has been widely understood to be an advancement to the CAPM model by claiming that beta has little or no ability to explain the cross-sectional variations in equity returns. Researchers argue that the theory should be accepted as a valid theory unless proven otherwise.

A limitation to testing the Fama and French three-factor model is difficulties surrounding the nature and construction of the size and book-to-market factors when compared to its simpler counterpart, the Capital Asset Pricing Model (Faff, 2001). However, the tests on the Fama and French threefactor model have been made possible as a result of the creation of off-the-shelf Fama and French factors. Faff (2001) and Long Pham (2007) have been instrumental in proposing methods to examine the validity of the threefactor model by creating and testing the Fama and French factors.

Dimson and Marsh (1999) argue that the size premium does not exist in relation to UK firms, especially after periods of recession. Gompers and Metrick (1998), as well 
as Bhardwaj and Brooks (1993), also show that the size effect was reversed, from the point of view of larger institutions outperforming smaller institutions in the former and large firms outperforming smaller firms on a riskadjusted basis in the latter. Similar findings were found in the Far East in countries like Japan as argued by Ziemba and Schwartz (1991).

Various studies have tried to explain these anomalies. For instance, Banz (1981) suggests that a reversal of size effect on beta could be seen during periods of recession. Furthermore, Carhart (1997) argue that the Fama and French three-factor model does not accurately capture equity performance and that a fourth factor would need to be introduced to achieve this. However, Dimson and Marsh (1999) performed a comprehensive study on possible causes of a negative size premium and cited survivorship bias of smaller firms and sector exposure as possible causes for the anomaly.

The research on the Fama and French model has mainly revolved around the performance of the model when tested in developed markets. For instance, Faff (2003) and Long Pham (2007) show evidence of the validity of the Fama and French model in countries like Australia and Japan. Nevertheless, there has not been enough work in relation to the Fama and French model when it comes to developing countries. More notably, there is very little evidence that the Fama and French model has been tested when it comes to the Islamic capital markets in developing countries.

This study will, therefore, seek to test the validity of the Fama and French three-factor model in the context of the Islamic stock market in a developing country such as Malaysia. The Islamic capital markets have been growing rapidly in developing countries in recent years and the study of the Fama and French model would provide researchers and fund managers with useful results.

In an attempt to bridge the gap between the conventional and Islamic Finance in the area of equity style index, Islamic equity style index has been developed initially from 2006 to 2011 as discussed in Shaharuddin, Lau, and Ahmad (2017a, 2017b). The interaction between the indices has also be studied by Shaharuddin et al. (2017c) This period is chosen in order to test the Fama and French model before and after the Global Financial Crisis and also to test the existence of the reversal of size effect anomaly.

The methodology employed in this study is the Generalized Method of Moments (GMM) methodology which was introduced by Lars Peter Hansen (1982). The benefit of applying this method is that it provides a general estimator that overcomes problems relating to the assumption of normality in distribution and also provides consistent variance estimates.
The results show that the performance of the Islamic unit trust funds follows the Fama and French three-factor model and the size and value effect does exist. However, the presence of negative size betas both before and after the Global Financial Crisis would indicate that the reversal of size effect exists in relation to the Islamic unit trust funds in Malaysia.

The remainder of the paper is organized as follows. Section 2 reviews the growth of the Islamic unit trust fund industry in Malaysia while Section 3 provides the literature review on the Fama and French three-factor model in relation to Islamic unit trust funds. Section 4 presents the methodology used to analyze the Islamic stock market data. Section 5 presents the results, followed by structural break test developed by Bai and Perron (2003). This is followed by a discussion on trading strategies of the newly created Islamic equity style indices. Finally, Section 6 discusses the implications together with suggestions for further research.

\section{The Growth of Islamic Unit Trust Fund Industry in Malaysia}

The Islamic unit trust fund industry has been growing significantly over the last ten years. The first Islamic unit trust fund was introduced in Malaysia in 1993 with the introduction of the Arab Malaysian Tabung Ittikal. Since then, the total number of Islamic unit trust funds has increased to 198 with a total net asset value (NAV) of RM49 billion worth of funds under management as at 31 July 2015.

The Securities Commission of Malaysia (SC) has promoted the development of Shariah-compliant Islamic stocks which provides opportunities for fund managers to diversify their portfolios. The SC has also placed a lot of emphasis on improving the unit trust fund industry by improvements to the regulations of the mutual fund industry which favours investors. The improvements to these regulations have been tabled in the most recent Capital Master Plan 2 (CMP2). Among other things, there are new rules that encourage public investment in mutual funds by enabling them to have easy access to information regarding the funds which they have invested in. Also, fund managers are also required to report fully their risk management procedures, processes, methods and investment strategies at least every quarter. Table 1 below provides a summary of Islamic unit trust funds in Malaysia according to NAV and number of funds. Figure 1 below, on the other hand, summarizes Islamic unit trust funds based on NAV and number of funds. 
Table 1: Total Number of Funds and Net Asset Value of Islamic Unit Trust Funds in Malaysia between June 2006 to June 2015

\begin{tabular}{|c|c|c|}
\hline Date & Number of Funds & $\begin{array}{c}\text { Total Net Asset Value } \\
\text { (RM billion) }\end{array}$ \\
\hline June 2006 & 87 & 8.75 \\
\hline June 2007 & 113 & 12.26 \\
\hline June 2008 & 136 & 17.54 \\
\hline June 2009 & 143 & 19.71 \\
\hline June 2010 & 156 & 22.69 \\
\hline June 2011 & 160 & 26.18 \\
\hline June 2012 & 168 & 31.37 \\
\hline June 2013 & 180 & 37.55 \\
\hline June 2014 & 186 & 45.27 \\
\hline June 2015 & 198 & 49.25 \\
\hline
\end{tabular}

Shariah Compliant Unit Trust Funds

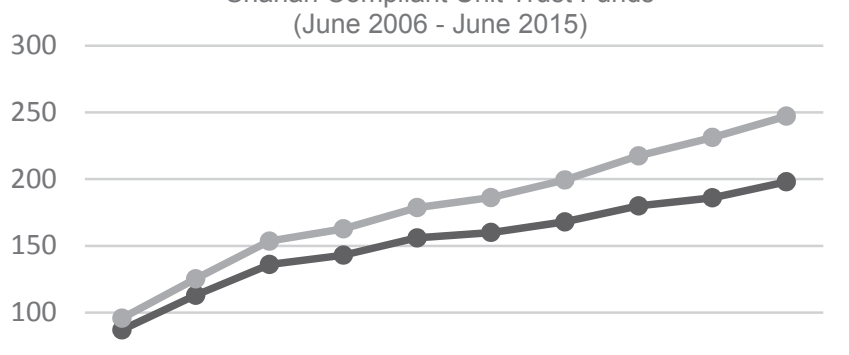

50

0

June June June June June June June June June June 2006200720082009201020112012201320142015

$$
\begin{aligned}
& - \text { Total Net Asset Value (RM billion) } \\
& \longrightarrow \text { Number of Funds }
\end{aligned}
$$

Figure 1: Total Number of Funds and Net Asset Value of Islamic Unit Trust Funds in Malaysia between June 2006 to June 2015

Figure 1 above clearly shows that there is an increase in importance in Islamic unit trust funds in Malaysia. An analysis of the above chart indicates that there is a 463 percent (or RM41 billion) increase in NAV from June 1996 to June 2015. On the other hand, there is a 128 percent increase (or an increase of 111 funds) in the total number of Islamic unit trust funds during the same period.

The growth of the Islamic mutual fund industry in Malaysia has further highlighted the importance of implementing new methods to further improve the management of the mutual funds. Style based investing as proposed by Sharpe (1992) as well as Fama and French (1992) will help to aid in the management of Islamic unit trust funds. Consequently, fund managers can benefit by adopting the newly created Islamic equity style indices in order to manage their portfolios. By testing the Fama and French three-factor model against Islamic unit trust funds, this will hopefully help fund managers to utilize Islamic equity style indices for purposes of portfolio management.

\section{Fama and French Three-Factor Model}

A style-based approach to analyzing the performance of companies was theoretically explained by Fama and French (1992) and their findings that cross-sectional variations in data do not fully explain fund performance in what is commonly known as the three-factor model. Their work was later tested and analyzed by various researchers.

The underlying assumption of the three-factor model is that companies with different style characteristics, such as size and value characteristics perform in a similar way. However, it has been argued that the Fama and French three-factor model is not valid under all conditions. Furthermore, there is a void in the literature when it comes to the analysis of the validity of the Fama and French threefactor model in developing economies. This gap is even more noticeable when it comes to the Islamic equity style stocks in developing countries.

The findings so far are mixed when it comes to the Fama and French three-factor model. While some studies have shown evidence that the three-factor model is valid, there have been observations which indicates that the Fama and French factors perform unexpectedly. For instance, the reversal of size effect is observed by Dimson and Marsh (1999), Faff (2003), and Long Pham (2007). They show that size and value betas are negative after an economic recession. Furthermore, whilst market risk premiums of size and value factors are positive and significant, they do not necessarily provide returns above the market premium. Nonetheless, investors and fund managers still seem to place an emphasis on developing investment portfolios using style-based techniques.

Notwithstanding the scrutiny against the model, researchers have developed new models as an extension to the Fama and French three-factor model. For instance, Breloer, Hendrik, and Wilkens (2014) find that when it came to mutual funds, the country momentum and sector momentum factors explain more than 50 percent of the funds are significantly affected by these factors. Interestingly, when viewed in comparison to the Islamic equity market, Merdad, Hassan, and Hippler (2015) find that an extension to the Fama and French model by introducing an Islamic effects factor would be a better approach when it comes to pricing Islamic equity stocks. 
Nonetheless, the Fama and French three-factor model has come under a lot of criticism. For instance, the empirical evidence suggests that beta is not robust under the Fama and French model and is still subject to scrutiny. Kothari, Shanken, and Sloan (1995) for instance argue that the sampling period needs to be lengthened in order to estimate beta. Also, as argued by Amihud, Bent and Mendelsohn (1992), the econometric methods applied only partially explain the Fama and French asset pricing model. Nevertheless, the three-factor model has gained in importance in the real world as a method to manage funds despite the criticisms against the model.

Prior research indicates that there are diversification benefits by choosing to select emerging market equity stocks in a portfolio. For instance, the benefits of a selection of emerging market funds are made even more attractive when compared to the performance of developed market funds during periods of economic crisis. Ajmi, Hammoudeh, Nguyen, and Sarafrazi (2014) however argue that decoupling of the Islamic market from their conventional counterparts reduces the portfolio benefits from diversification.

Islamic equity funds have been argued to outperform conventional funds during times of financial crises. Nonetheless, the results are mixed when it comes to the diversification benefits of emerging market mutual funds. For instance, there is evidence that although Islamic funds are safer and less affected by the financial crises, the performance of the fund is not attractive enough for funds managers and investors (Makni, Benouda, \& Delhoumi, 2015). Furthremore, Kassim, and Kamil (2012) and Ho, Rahman, Yusuf, and Zamzamin (2014) provide some evidence that Islamic funds are in fact a better choice for investors in Malaysia during the financial crisis periods. In a recent paper, Dewandaru, Rizvi, Masih, Masih, and Alhabshi (2014) argued that Islamic equities due to their low leverage do not provide good diversification benefits and they are highly vulnerable to other financial crises.

When it comes to the behavior of emerging market fund managers, research seems to suggest that Islamic fund managers have a preference for growth and large stocks (Waulkhausl, There is no reference 2012). Similar findings were made by Girard, There is no reference (2007) where Islamic indices are compared to conventional indices that Islamic indexes are growth and small-cap oriented and conventional indices are more value and mid-cap focused. Investors, on the other hand, have been proven to chase hedge fund investment styles with funds which are better performing (Horst \& Salganik, 2014).

The study on Islamic unit trust funds was also performed by comparing the performance of Islamic equity funds (IEF) as compared to conventional equity funds. Current literature provides evidence that even though IEF's benefits from stock selection methods which are based on religious and moral selection standards, they do not necessarily provide investors with stable and abnormal returns. For instance, the studies by Hayat and Kraeussl (2011) and Abdullah, Hassan, and Mohamad (2007) indicate that IEF does not perform as well as Islamic or conventional indices. Renneboog, Horst, and Zhang (2008) also discover that socially responsible funds do not necessarily outperform conventional funds.

This finding, however, was later refuted by Abdelsalam et al. (2014) who argue that Islamic funds do in fact outperform socially responsible funds. Nonetheless, there are various studies which argue that IEF benefit from Islamic screening standards and selection standards thus outperforming their conventional counterparts (Mohammad et al., 2015).

Research in the area of Islamic equity funds, however, has been extended to the area of examining the performance and behavior of funds managers. Fund managers have been found to be inefficient when it comes to making investment decisions, specifically when it comes to the timing and selection of Islamic stocks to which are included in a portfolio. The performance of Islamic fund managers was further studied by Lai and Lau (2010) as well as Bashir and Nawang (2011). The performance of fund managers for Islamic equity style stocks, in fact, was highlighted and it was found that fund managers have poor timing ability and they are unable to correctly identify good bargain stocks (Bashir \& Nawang, 2011).

The generalized method of moments methodology introduced by Lars Peter Hansen (1982) however has proven to be an effective method for analyzing the Fama and French three-factor model. The research thus far has shown evidence that the Fama and French model is valid under various different settings. Wei and Chiang (2004) argue that the GMM is especially a useful method when it comes to analyzing daily returns that are non-normal for most financial assets as the GMM estimator is simpler to apply as compared to the maximum likelihood estimator. Walid and Lau (2009) on the other hand has done a follow up on the research by Faff (2003) whilst constructing a Russell/Nomura style index and supported the claims made by prior research. The results from the study were derived from the Generalized Method of Moments (GMM) technique. In doing so, the analysis managed to show evidence that the Fama and French model is more reflective of the Japanese stock market.

The evidence from the literature seems to indicate that there is a need to perform further studies on Islamic mutual funds in relation to the Fama and French model. A more comprehensive and in-depth study of the performance of Islamic stocks when applied against the Fama and French 
three-factor model would be beneficial to fund managers and investors who intend to make asset allocation decisions based on Islamic stocks. The study of the performance of Islamic stocks based on other asset pricing models which have followed from the three-factor model would also be valuable to prospective investors.

\section{Empirical Framework}

In describing the three-factor model, Fama and French (1993) ascertained a theoretical model to explain the stylized effects of two additional factors namely SMB and HML factors which serves as an addition to the existing CAPM model. The three-factor model is described in Equation (1) based on Long Pham (2007):-

$$
E(\tilde{R})_{i}-R_{f}=b_{i}\left[E\left(\tilde{R}_{M}-R_{f}\right)\right]+s_{i} E\left(\tilde{R}_{S M B t}\right)+h_{i} E\left(R_{H M L t}\right)
$$

Where $\mathrm{E}(\tilde{R})_{i}-R_{f}, \quad \mathrm{E}(\tilde{R})_{m}-R_{f}, \quad \mathrm{E}\left(\tilde{R}_{S M B t}\right), \quad\left(R_{H M L t}\right)$ represent the expected excess return on asset i, the expected excess return on the market portfolio, the expected return on a proxy portfolio for the "small minus big" size factor, the expected return on a proxy portfolio for "high minus low" book-to-market factor, respectively.

We obtain the factor loadings $b_{i}, s_{i}$, and $h_{i}$ from the slopes of the empirical counterpart in Equation (2):-

$$
\tilde{R}_{i t}-R_{f}=\alpha_{i}+b_{i}\left(\tilde{R}_{M t}-R_{f}\right)+s_{i} \widetilde{R}_{S M B t}+h_{i} R_{H M L t}+\widetilde{\varepsilon}_{i t}
$$

where $R_{i t}-R_{f}$, RMT- $R_{f}$, RSMB, t RHMLt denote the realized excess return on asset $i$, the realized excess return on the market portfolio, the realized return on a proxy portfolio for size factor and the realized return on a proxy portfolio for the book-to-market factor at time $\mathrm{t}$, respectively. The beta coefficients, $b_{i}, s_{i}$, and $h_{i}$ represent the sensitivity of the excess return on asset $i$ to changes in returns on common risk factors. Following from this, by taking the expectation of equation (2) and comparing it to equation (1), the intercept $\alpha$ is expected to be zero for all $i$.

Using Faff's (2003, 2004) methodology of introducing GMM to test the Fama and French model, we develop the following system of equations:

$$
\begin{aligned}
& \tilde{R}_{i t}-R_{f}=b_{i}\left(\tilde{R}_{M t}-R_{f}\right)+s_{i} \tilde{R}_{S M B t}+h_{i} \tilde{R}_{H M L t}+\widetilde{\varepsilon}_{i t} \\
& \tilde{R}_{M t}-R_{f t}=\mu_{M}+\tilde{\xi}_{t}
\end{aligned}
$$

$$
\begin{aligned}
& \tilde{R}_{S M B t}=\mu_{S M B}+\tilde{\Psi}_{t} \\
& \tilde{R}_{S M B t}=\mu_{H M L}+\tilde{\omega}_{t} \\
& i=1,2, \ldots \ldots \ldots \ldots N
\end{aligned}
$$

where $\mu_{\mathrm{M}}, \mu_{\mathrm{SMB}}, \mu_{\mathrm{HML}}$ are the estimated market premium, SMB premium, and HML premium, respectively. Correspondingly, there are seven sample moments in this system of equations namely:

$$
\begin{gathered}
\left(1 / T \sum_{t=1}^{T} \widetilde{\varepsilon}_{i t}, 1 / T \sum_{t=1}^{T} \widetilde{\varepsilon}_{i t}\left(\widetilde{R}_{M t}-R_{f}\right), 1 / T \sum_{t=1}^{T} \widetilde{\varepsilon}_{i t} \widetilde{R}_{S M B t},\right. \\
\left.1 / T \sum_{t=1}^{T} \widetilde{\varepsilon}_{i t} \widetilde{R}_{H M L t}, 1 / T \sum_{t=1}^{T} \widetilde{\xi}_{i t}, 1 / T \sum_{t=1}^{T} \widetilde{\psi}_{i t}, 1 / T \sum_{t=1}^{T} \widetilde{\omega}_{i t}\right)
\end{gathered}
$$

Also, there are six parameters $\left(b_{i}, s_{i}, h_{i}, \mu_{\mathrm{M}}, \mu_{\mathrm{SMB}}, \mu_{\mathrm{HML}}\right)$ to be estimated for each asset. Since the system is overidentified (i.e. having more known than unknown variables), the test for assessing identification is conducted to verify whether moment restrictions are valid or not. Under the null hypothesis, the moment restrictions are found to be valid, implying the choice of FF model is appropriate.

The GMM methodology is used in this case due to its superiority over the ordinary least squares (OLS) method. These benefits include the fact that the modeling estimation method provides for a general estimator which in fact encompasses other estimation methods ineluding maximum likelihood method as well as incorporating instrumental variables. Furthermore, GMM is an efficient method that can be used to avoid biases in calculating test statistics.

\subsection{Data and Variables}

Monthly data from May 2006 to I April 2011 is used. This period is chosen to coincide with the Shariah Listing of Shariah Compliant Securities from the Securities Commission of Malaysia. Shariah Compliant Securities are stocks listed on the Kuala Lumpur Stock Exchange (KLSE) which are approved by the Shariah Advisory Council (SAC) of the Securities Commission.

These data are available from e Bank Negara Malaysia (Central Bank of Malaysia), Securities Commission of Malaysia (SC), Department of Statistics of Malaysia as well as from Thomson Reuters Datastream. For data which is not available in the form of mon(thil) data, the Cubic Spline is employed to determine monthly data points. (Refer to Appendix A for discussion on C(4)ic Spline). 
The choice of the market index in this study is based on the Islamic equity style indices as derived from the Malaysian Shariah stock market. The Islamic equity style index is then used to construct the Fama and French 'SMB' and 'HML' factors which are developed by using the Russell Company method. These newly developed Islamic equity style indices are identified as Large Growth (LG), Large Value (LV), Core Growth (MG), Core Value (MV), Small Growth (SG) and Small Value (SV). The risk-free rate is based on the Malaysian Treasury Bill rate.

To further explain, the Islamic growth stocks (LG and LV) are taken from the top 30 largest Shariah-compliant companies listed on the Kuala Lumpur Stock Exchange. The Core Value (MV) and Core Growth (MG) stocks represent the following 70 largest stocks. The SV and SG stocks represent the remaining 98 percent of stocks in the universe of Islamic stocks.

\subsection{Creation of Malaysian Islamic Equity Style Indices}

The LV, LG, SV, and SG Malaysian Islamic Fama and French factors are developed by using data from the list of Shariah Compliant Shares traded on the FTSE EMAS Shariah Index. Malaysian Islamic Equity style LG, LV, SG, and SV indices are then derived from the KLSE Shariah Index using the Frank Russell Company Method in creating sub-indices. The Malaysian Islamic unit trust funds data which shall be used for purposes of this study are derived from Reuters Datastream. For further explanation regarding the relationship between the indices, refer to Figure 2 below:

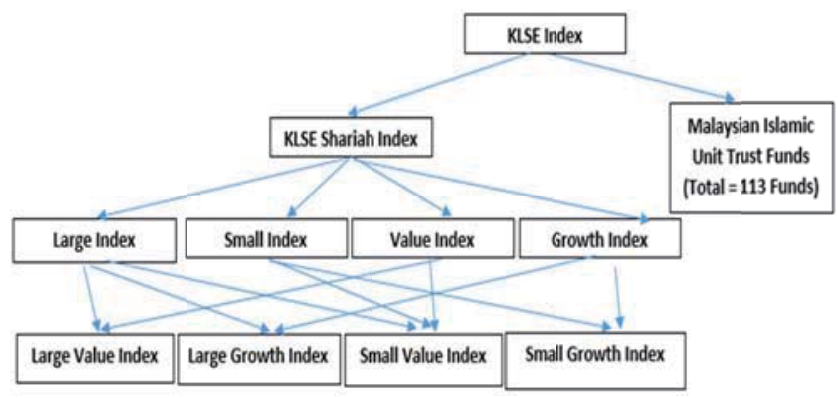

Figure 2: Relationship between KLSE Shariah Equity Style Indices and Malaysian Islamic Unit Trust Funds

Once the Islamic Equity style indices of growth and value factors have been created, they are then used to determine the returns of small minus big 'SMB' and high minus low 'HML' book-to-market factor. These factors can be described as follows:-

$$
\begin{aligned}
& S M B t=\left(\frac{R S V t+R S G t}{2}\right)-\left(\frac{R L V t+R L G t}{2}\right) \\
& H M L t=\left(\frac{R L V t+R S V t}{2}\right)-\left(\frac{R L G t+R S G t}{2}\right)
\end{aligned}
$$

where RSGt is the return of the SG index in the period t, $R L V t$ is the return on the LV index in period $t$ and the $L G$ is the return on the LG index in period $t$.

Figure 3 below illustrates the performance of Fama and French factors as derived from Equation 7 and 8 during the period May 2006 to April 2011. The SMB and HML factors appear to be correlated and perform in a similar fashion before and after the financial crisis period (financial crisis period was identified as August 2008). The chart also indicates that both SMB and HML factors are more volatile prior to and right after the financial crisis period and is less volatile during periods of recovery in late 2009. Furthermore, it appears that the size factor (SMB) tends to be more volatile as compared to the value factor $(\mathrm{HML})$.

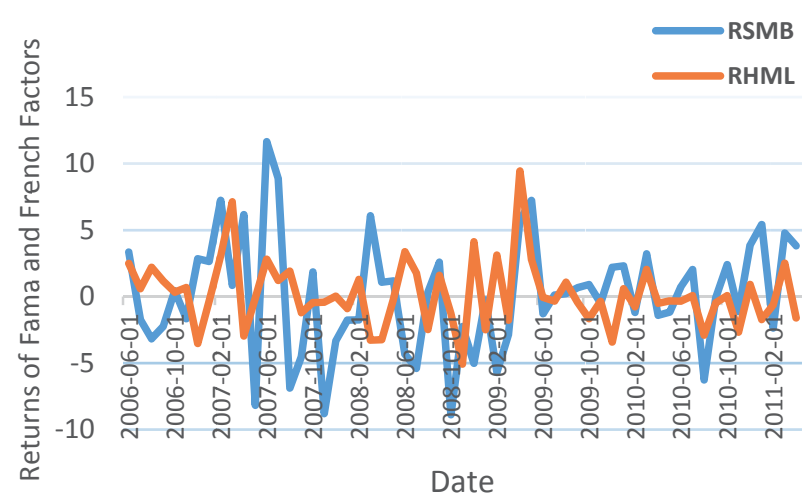

Figure 3: Performance of Fama and French Factors from May 2006 to April 2011

In creating the Malaysian Islamic Equity style indices for purposes of deriving the FF factors, there were certain limitations from the point of view of the availability of data which needs to be used for the purpose of constructing the indices. We have dealt with this issue by carefully selecting companies which are listed on the Shariah Compliant list of companies and also has data available from Reuters Datastream. However, certain companies have been deliberately excluded from the indices due to unavailable data. 


\subsection{Descriptive Statistics}

Table $2 \mathrm{~A}$ and $2 \mathrm{~B}$ below provides basic descriptive statistics of the newly created Islamic FF factors for the precrisis and post-crisis period respectively. In analyzing the tables, it can be observed that the average SMB and HML premiums are positive for both pre and post-crisis periods. This finding is similar to that of Fama and French (1993) which argues for a positive FF premium. Also, the market factor produces the highest average return and the highest standard deviation across both sub-periods. This is not consistent with Fama and French's (1992) study which argues that the average return of the market is lower than the FF factors. However, the results are similar when it comes to the standard deviation of the market returns across both sub-periods.

Table 2A: Pre-Crisis Period Basic Descriptive Statistics and Correlations Between FF Factors

\begin{tabular}{|c|c|c|c|}
\hline \multicolumn{4}{|l|}{ Descriptive Statistics } \\
\hline & RM & SMB & HML \\
\hline Mean & 0.7314 & 0.0245 & 0.3975 \\
\hline Median & 1.4272 & 0.3365 & 0.3262 \\
\hline Max & 9.3453 & 11.6461 & 7.1141 \\
\hline Min & -8.0949 & -8.8007 & -3.5360 \\
\hline Standard Deviation & 4.4872 & 5.0869 & 2.3994 \\
\hline \multicolumn{4}{|l|}{ Correlation Matrix } \\
\hline & RM & SMB & HML \\
\hline RM & 1.0000 & & \\
\hline SMB & 0.1395 & 1.0000 & \\
\hline $\mathrm{HML}$ & -0.0183 & -0.0461 & 1.0000 \\
\hline
\end{tabular}

Table 2B: Post-Crisis Period Basic Descriptive Statistics and Correlations Between FF Factors

\begin{tabular}{|l|c|c|c|}
\hline Descriptive Statistics & RM & SMB & HML \\
\hline & 1.1610 & 0.2396 & -0.0226 \\
\hline Mean & 1.2511 & 0.1625 & -0.3554 \\
\hline Median & 13.5454 & 7.2273 & 9.4306 \\
\hline Max & -15.2226 & -8.8989 & -5.0792 \\
\hline Min & 4.8429 & 3.6261 & 2.6235 \\
\hline Standard Deviation & RM & SMB & HML \\
\hline Correlation Matrix & 1.0000 & & \\
\hline \multicolumn{4}{|l|}{} \\
\hline RM & 0.4609 & 1.0000 & \\
\hline SMB & 0.3895 & 0.3142 & 1.0000 \\
\hline HML &
\end{tabular}

Results from the correlation matrix in both sub-periods indicate that the FF factors are weakly correlated with one another. The strongest degree of correlation is between the SMB factor against the market factor $(0.46)$ during the postcrisis period. The lowest degree of correlations is between the HML factor when compared against the SMB factor
(-0.02) during the pre-crisis period. Similar findings were found by Fama and French (1993).

\subsection{Structural Break Test}

Results of the structural break test using Bai and Perron's (2003) methodology to test for multiple structural breaks is summarized in Table 3 below. The F statistic rejects the null hypothesis of no structural break in the case of all the series. The multiple breakpoint tests find the presence of five breakpoints for GDP, four breakpoints for KLCI, LEI, LG, and LV as well as two breakpoints in the case of IPI.

However, similar break dates which were reported on August 2008 for KLCI, LEI, LG, and LV indices corresponds to the expected structural break at the time of the Lehman Bros. collapse which or the beginning of the Global Financial Crisis. We have therefore divided the period of the study into periods before and after the collapse of Lehman Bros. to improve statistical inferences.

Table 3: Bai and Perron (2003) multiple structural break test results

\begin{tabular}{|c|c|c|c|c|}
\hline Variable & $\begin{array}{l}\text { Number of } \\
\text { breakpoints }\end{array}$ & $\begin{array}{c}95 \% \text { Confidence } \\
\text { intervals for break } \\
\text { dates }\end{array}$ & $\begin{array}{c}\text { F- } \\
\text { Statistic }\end{array}$ & $\begin{array}{c}\text { BP(2003) } \\
\text { Critical } \\
\text { Value }\end{array}$ \\
\hline GDP & 5 & $\begin{array}{c}\text { 2007M02, 2007M11, } \\
\text { 2008M11, 2009M08, } \\
\text { 2010M06 }\end{array}$ & 123.03 & 3.91 \\
\hline $\mathrm{KLCl}$ & 4 & $\begin{array}{c}\text { 2007M02, 2007M11, } \\
\text { 2008M08, 2009M07, } \\
\text { 2010M08 }\end{array}$ & 82.91 & 4.99 \\
\hline IPI & 2 & 2007M07, 2008M11 & 44.31 & 7.22 \\
\hline LEI & 4 & $\begin{array}{c}\text { 2007M02, 2007M11, } \\
\text { 2008M08, 2009M07, } \\
\text { 2010M08 }\end{array}$ & 50.86 & 4.99 \\
\hline LG & 4 & $\begin{array}{c}\text { 2007M02, 2007M11, } \\
\text { 2008M08, 2009M07, } \\
\text { 2010M08 }\end{array}$ & 68.26 & 4.99 \\
\hline LV & 4 & $\begin{array}{c}\text { 2007M02, 2007M11, } \\
\text { 2008M08, 2009M05, } \\
\text { 2010M03 }\end{array}$ & 68.32 & 4.99 \\
\hline
\end{tabular}

The empirical tests which shall be performed in order to test the Fama and French three-factor model will be conducted by dividing the data set into two sub-periods, before and after the Lehman Brothers Co. collapse in August 2008. Segmentation of the Fama and French threefactor model over two sub-periods is also done to test the robustness of the model in periods before and after a Global Financial Crisis.

Summary of betas and GMM test results of the FF model during the pre-Lehman period is presented in Table B.1 and Table B.2 of Appendix B. With respect to market betas, 77 from 103 market betas are statistically significant. Also, 75 
out of 103 market betas are statistically significant at 1 percent level. However, when it comes to the size factor, there were a total of 24 betas out of 103 betas which were statically significant and 5 size betas were negative and significant. Finally, there are 16 value betas which were statistically significant and 14 out of 103 value betas were both negative and statistically significant.

The analysis of the risk premium of the Islamic unit trust indicates that the highest market beta is 1.597 and the lowest market beta is -0.759 . The results also suggest that a large majority (100 funds or 97 percent of funds) have positive market betas. A total of 8 percent of Islamic unit trust funds have market betas above 1 and could be regarded as risky funds. In comparison, 46 unit trust funds (or 45 percent of funds) have negative size betas with the smallest size beta at -1.151 and highest size beta at 0.929 . Lastly, with respect to value betas, there are a larger number (56 funds or 54 percent) of funds with the lowest value beta at -1.158 and the highest value beta at 0.929 .

The GMM test results for the pre-Lehman Bros. subperiod is summarized in Table 4 below. The Sargan test statistic in Table 3 indicates that the FF model cannot be rejected in 84 percent of the cases. However, from the total funds analyzed in the pre-Lehman Bros. period, 10 percent of the funds or 10 funds have a test statistic between 0.10 to 0.20 and only marginally passed the GMM test. The preLehman Bros. test results show evidence that a significant number of funds passed the GMM test and that the results follow the Fama and French model.

Table 4: Pre-Lehman Bros. Sargan Test Statistics

\begin{tabular}{|c|c|}
\hline Sargan Test Statistics & Number of Islamic unit trust funds \\
\hline Less than 10 percent & 19 \\
\hline Above 10 percent & 84 \\
\hline Total & 103 \\
\hline
\end{tabular}

The larger number of positive and statistically significant market betas would suggest that the Pre-Lehman Bros. unit trust funds performance follows the FF model. Also, the larger number of positive and statistically significant size betas also favors the three-factor model. However, the fewer number of positively significant value factors does not follow the three-factor model. The results of the GMM test statistics, however, would suggest that the Fama and French model should be accepted in most cases during the Pre-Lehman Bros period.

Table B.3 and Table B.4 of Appendix B, on the other hand, presents GMM test results and summary market, SMB and HML betas for the post-Lehman Bros. sub-period. The results of the analysis indicate that 92 percent (95 funds) have a positive market beta. Nonetheless, only 31 percent
(32 funds) and 21 percent (22 funds) have significant size and value factors respectively. The mean market beta, size and value beta is also significantly below one in this case.

Furthermore, it is also observed that 69 percent (71 funds) and 40 percent (60 funds) of SMB and HML betas have positive betas respectively. Also, it could be shown that 47 percent (46 funds) have market betas below 0.5 and 94 percent (93 funds), as well as 96 percent (99 funds), have SMB and HML betas below. 0.5. In contrast, there are a larger number of funds with a market beta above 0.5 (47 percent, or 48 funds).

The analysis of the GMM test results is summarized in Table 5 below. This table indicates that the FF model cannot be rejected in 80 percent of the cases. Also, 12 percent (12 funds) show a GMM test statistic between 0.1 and 0.2 . When compared against the pre-Lehman Bros. sub-period, there is evidence to show that even though there are fewer GMM test results which support the Fama and French model in the post-Lehman Bros. sub-period, the overall results show evidence that the Fama and French model cannot be rejected. The results also indicate that even in comparison with the pre-Lehman Bros. sub-period, there are a larger number of positive SMB betas while there are fewer positive HML betas.

Table 5: Post-Lehman Bros. Sargan test statistics

\begin{tabular}{|c|c|}
\hline Sargan Test Statistics & Number of Islamic unit trust funds \\
\hline Less than 10 percent & 23 \\
\hline Above 10 percent & 80 \\
\hline Total & 103 \\
\hline
\end{tabular}

Given the results of the analysis over the two sub-periods, there is evidence to show that the FF model though accepted in most cases, suffers from low and negative risk premiums. The results also agree with findings by Dimson and Marsh (1999) who argue for a reversal of size effects across both sub-periods.

\subsection{Trading Strategies}

The significance of the newly developed Islamic equity style for investors and the fund manager can be explained by undertaking simple trading strategies. A trading strategy can be useful to evaluate the predictability of asset returns and to formulate investment strategies to see whether an economically significant profit can be generated (Fama \& Schwert, 1977). The trading strategies which we shall employ can be divided into buying and selling stock portfolios based on SMB (small minus large market capitalization) and HML (high minus low B/P or value minus growth) stocks. These trading strategies will be further 
divided into three sub-periods to include the full period of the study, the pre-crisis period and post-crisis period. The results from these trading strategies are further explained in Table C of Appendix C.

The results from Appendix B suggests that there is a benefit of creating portfolios of Islamic stocks based on Fama and French size and value factors. The value stocks seem to outperform growth stocks with an annualized return of 3.13 percent for the full period of the study. Highest investment returns could be achieved by buying value and selling growth stocks during the pre-crisis period (annualized return of 5.90 percent). However, the post-crisis period results seem to indicate that selecting stocks based on size (buying small and selling large cap) stocks yield better returns as compared to selecting stocks based on value and growth characteristics.

\section{Conclusion}

The findings suggest that the FF model can be explained by testing the model in the setting of Islamic unit trust funds. These results also support the claims made by similar analysis of stock markets in the Far East in countries like Japan and Australia. The results of the study also concur with findings by Dimson and Marsh (1999), Faff (2001), Long Pham (2007) and others in relation to the existence of the reversal of size effect anomaly. Together with an overall acceptance of the GMM test results, this study provides evidence to suggest that the Fama and French model is valid when it comes to the performance of Islamic unit trust funds.

The evidence would also suggest that fund managers and investors could benefit by using Islamic unit trust funds as an option for purposes of investing and diversifying funds. For purposes of portfolio selection, studies should also be extended to test the performance of Islamic unit trust funds in comparison to conventional unit trust funds during periods before and after a financial crisis. The evidence from the simple trading strategies shows further evidence that value and small capitalization stocks are beneficial when it comes to creating investor portfolios.

From the point of view of the Islamic capital markets in an emerging economy, the evidence shows that the Fama and French three-factor model is valid and useful to investors and fund manager. It would also be interesting to see how the newly created off-the-shelf FF factors perform assuming the study is extended to more current models such as the Carhart (1997) model when tested against Islamic unit trust funds. The studies relating to Islamic equity funds have so far have encompassed areas relating to diversification benefits and the behaviour of Islamic equity fund managers.

\section{References}

Abdullah, F., Hassan T., \& Mohamad, S. (2007). Investigation of the performance of Malaysian Islamic unit trust funds. Managerial Finance, 33(2), 142-153.

Abdelsalam, O., Duygun, M., Matallín-Sáez, J., \& TortosaAusina, E. (2014). Do ethics imply persistence? The case of Islamic and socially responsible Funds. Journal of Banking \& Finance, 40 (2014) 182-194.

Ajmi, A. N., Hammoudeh, S., Nguyen, D. K., \& Sarafrazi, S. (2014). How strong are the causal relationships between Islamic stock markets and conventional financial systems? Evidence from linear and non-linear tests. International Financial Markets, Institutions, and Money, 28(C), 213227.

Amihud, Y., Bent, J. C., \& Mendelson, H. (1992). Further evidence on the risk-return relationship. Salomon Brothers Center for the Study of Financial Institutions, Graduate School of Business Administration, New York University. Working Paper No. 1248.

Bai, J., \& Perron, P. (2003). Computation and analysis of multiple structural change models. Journal of Applied Economics, 18, 1-22.

Banz, R. W. (1981). The relationship between return and market value of common stock. Journal of Financial Economics, 9(1), 3-18.

Bashir, M., \& Nawang, W. (2011). Islamic and Conventional Unit Trusts in Malaysia: A Performance Comparison. Research Gate Publication, Retrieved September 30, 2018 from https://www.researchgate.net/publication/ 236895453_Islamic_and_Conventional_Unit_Trusts_in_M alaysia_A_Performance_Comparison.

Bhardwaj, R., \& Brooks, L. (1993). Dual betas from bull and bear markets: Reversal of the size effect. Journal of Financial Research, 16, 269-83.

Breloer, B., Hendrik, S., \& Wilkens, M. (2014). Performance of international and global equity mutual funds: Do country momentum and sector momentum matter? Journal of Banking \& Finance, 43, 58-77.

Carhart, M. M. (1997). On persistence in mutual fund performance. Journal of Finance, 52, 57-82.

Dewandaru, G., Rizvi, S., Masih, R., Masih, M., \& Alhabshi, S. (2014). Stock market co-movements: Islamic versus conventional equity indices with multi-timescales analysis. Economic Systems, 38, 553-571.

Dimson, E., \& Marsh, P. (1999). Murphy's law and market anomalies: The size premium may have gone in reverse, but the size effect lives on. Journal of Portfolio Management, Winter, 53-69.

Faff, R. (2001). An examination of the Fama and French three-factor model using commercially available factors. Australian Journal of Management, 26(1), 1-17. 
Faff, R. (2003). Creating Fama and French factors with style. Financial Review, 38, 311-322.

Faff, R (2004). A simple test of the Fama and French model using daily data: Australian evidence. Applied Financial Economics, 14, 83-92.

Fama, E., \& French, K. (1992). The cross-section of expected stock returns. Journal of Finance, 47, 427-67.

Fama, E., \& French, K. (1993). Common risk factors in the returns on stocks and bonds. Journal of Financial Economics, 33, 3-56.

Fama, E., \& French, K. (1995). Size and book-to-market factors in earnings and returns. Journal of Finance, 50, 131-55.

Fama, E., \& French, K. (1996). Multifactor explanations of asset pricing anomalies. Journal of Finance, 51, 55-84.

Fama, E., \& French, K. (2015). A five-factor asset pricing model. Journal of Financial Economics, 1, 1-22.

Fama, E., \& Schwert, G. (1977). Asset returns and inflation. Journal of Financial Economics. 5, 115-146.

Hansen, L. P. (1982). Large Sample Properties of Generalized Method of Moments Estimators. Econometrica, 50, 1029-1054.

Hayat, R., \& Kraeussl, R. (2011). Risk and return characteristics of Islamic equity funds. Emerging Markets Review, 12, 189-203.

He, J., \& Ng, L. (1994). Economic forces, fundamental variables and equity returns. Journal of Business, 67 , 599-639.

Ho, C., Rahman, N. A., Yusuf, N. H., \& Zamzamin, Z. (2014). Performance of global Islamic versus conventional share indices: International evidence. Pacific-Basin Finance Journal, 28. 110-121.

Horst, J., \& Salganik, G. (2014). Style chasing by hedge fund investors. Journal of Banking \& Finance, 39, 29-42.

Gompers, P., \& Metrick, A. (1998). Institutional investors and equity prices, NBER Working Paper, 6723.

Granville, S. (2005). Application: Cubic Spline Interpolation, Computational Methods of Linear Algebra. Hoboken, $\mathrm{NJ}$ : Wiley-Interscience.

Kassim, S., \& Kamil, S. (2012). Performance of Islamic Unit Trusts during The Global Financial Crisis: Evidence From Malaysia. Asian Academy of Management Journal, 17(2), 59-78.

Kothari, S., Shanken, J., \& Sloan, R. (1995). Another look at the cross-section of expected stock returns. Journal of Finance, 50, 185-224.

Lai, M., \& Lau, S. (2010). Evaluating mutual fund performance in an emerging Asian economy: The Malaysian experience. Journal of Asian Economics, 21, 378-390.

Lintner, J. (1965). The valuation of risk assets and the selection of risky investments in the stock portfolios and capital budgets. Review of Economics and Statistics, 47, 1029-1054.

Long Pham, V. T. (2007). Constructing Fama-French Factors from style indexes: Japanese Evidence. Economics Bulletin, 7(7), 1-10.

Makni, R., Benouda, O., \& Delhoumi, E. (2015). Large-scale analysis of Islamic equity funds using a meta-frontier approach with data envelopment analysis. Research in International Business and Finance, 34, 324-337.

Merdad, H. J., Hassan, M. K., \& Hippler III, W. J. (2015). The Islamic risk factor in expected stock returns: An empirical study in Saudi Arabia. Pacific-Basin Finance Journal, 34, 293-314.

Mohammad, N., \& Ashraf, D. (2015). The market timing ability and return performance of Islamic equities: An empirical study. Pacific-Basin Finance Journal, 34 (2015) 169-183.

Renneboog, L., Horst, J., \& Zhang, C. (2008). The price of ethics and stakeholder governance: The performance of socially responsible mutual funds. Journal of Corporate Finance, 14, 302-322.

Sharpe, W. F. (1964). Capital asset prices: A theory of market equilibrium under conditions of risk. Journal of Finance, 19, 425-442.

Sharpe, W. (1992). Asset allocation: Management Style and Performance Measurement. Journal of Portfolio Management, Winter, 7-19.

Shaharuddin, S. S., Lau, W. Y., \& Ahmad, R. (2017a). Constructing Fama-French factors from style indices: Evidence from the Islamic Equity Market. Emerging Markets Finance and Trade, 53(7), 1563-1572. DOI: 10.1080/1540496X.2016.1278529.

Shaharuddin, S. S., Lau, W. Y., \& Ahmad, R. (2017b). New Islamic Equity Style Indices: Constructing and testing the efficacy of information transmission. Cogent Economics and Finance, 5, 1-19. DOI:10.1080/23322039.2017.1363355.

Shaharuddin, S. S., Lau, W. Y., \& Yip, T. M. (2017c). Dynamic Linkages between newly developed Islamic Equity Style Indices: Is growth style more influential than value style? Capital Market Review, 27(2), 49-64.

Walid, E. M., \& Lau, W. Y. (2009). Constructing the FamaFrench Model from Russell/Nomura Style Indexes: Japanese Evidence. International Review of Applied Financial Issues and Economics, 1(1), 20-32.

Wei, J., \& Chiang, R. (2004). A GMM approach for estimation of volatility and regression models when daily prices are subject to price limits. Pacific-Basin Finance Journal, 12, 445-461.

Ziemba, W., \& Schwartz, S. (1991). Invest Japan. Chicago, IL: Probus Publishing. 


\section{Appendix A}

Figure A.1 below illustrates the GDP of Malaysia (in Ringgit Malaysia) between May 2006 to April 2011. The method used to derive the GDP is based on the cubic spline method and allows for the interpolation of GDP values from a quarterly basis to a monthly basis (de la Granville, 2001).

The Cubic Spline method is used for purposes of interpolating quarterly economic data to produce monthly data which is relevant to this analysis. This method also enables the development of a smooth curve which interpolates values of monthly data. The Cubic Spline output was produced using MS Excel. The application of the Cubic Spline method in capital markets through the mathematical application of a piecewise polynomial function is explained by Granville (2005). A plot of monthly GDP (MYR) between May 2006 to April 2011 based on the Cubic Spline method is illustrated in Figure A.1 of Appendix A.

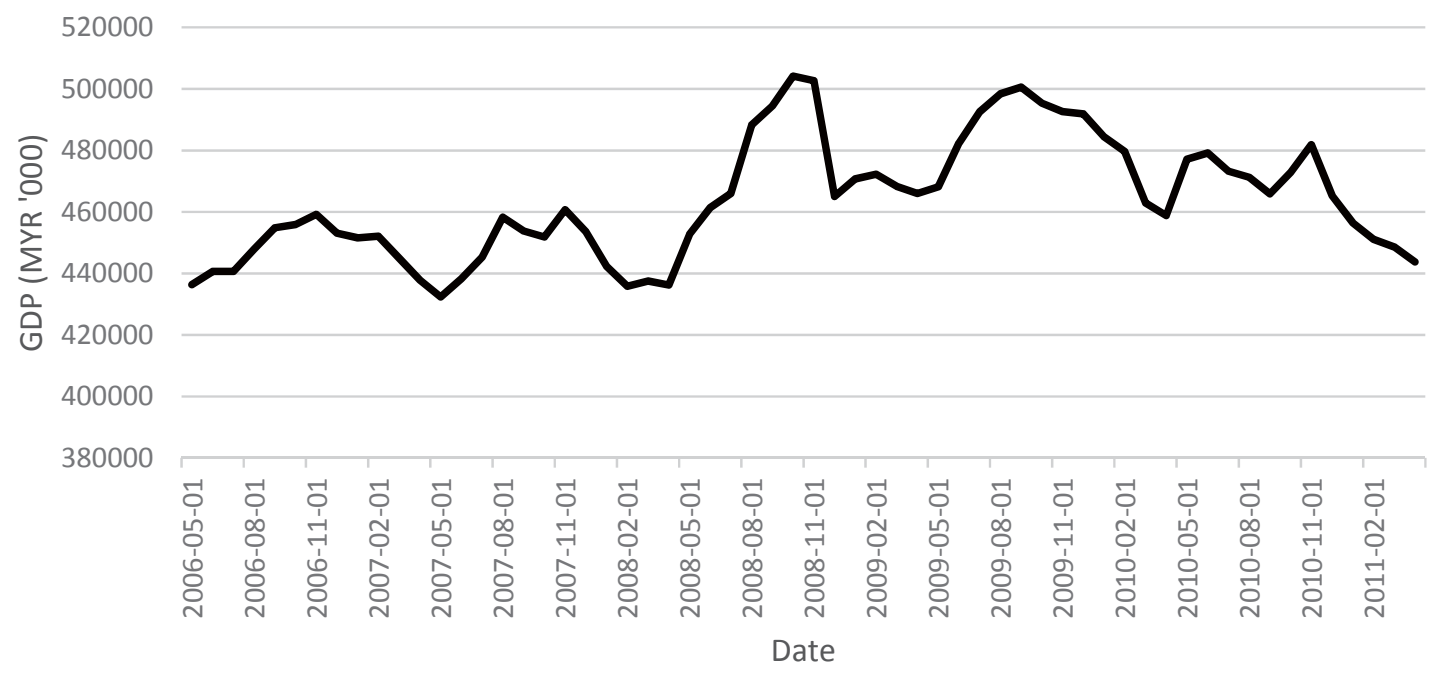

Figure A.1: GDP of Malaysia from May 2006 to April 2011 based on cubic spline interpolation

\section{Appendix B}

Table B.1, B.2, B.3 and B.4 below presents GMM test statistics based on Islamic unit trust funds in Malaysia for periods before and after the collapse of Lehman Bros. There are a total of 103 Islamic unit trust funds which were tested for the period between May 2005 and April 2011. The results GMM test results for the pre-Lehman Bros. period is presented in Table B.1 and corresponding summary betas in Table B.2. The post-Lehman Bros. sub-period results, on the other hand, are presented in Table B.3 and corresponding summary betas in Table B.4. 
Table B.1: Pre-Lehman Bros. Fama and French three-factor model tests based on GMM estimates

\begin{tabular}{|c|c|c|c|c|c|}
\hline No. & Unit Trust Fund & bi & si & hi & GMM \\
\hline 1 & AIA DANA DINAMIK & $0.875\left(20.393^{* * *}\right)$ & $0.810(0.107)$ & $-0.044 *(-0.531)$ & $6.020[0.013]$ \\
\hline 2 & AIA DANA PROGRESIF & $0.844\left(15.526^{* * *}\right)$ & $-0.041(-0.631)$ & $-0.056(-0.658)$ & $6.442[0.011]$ \\
\hline 3 & ALLIANCE DANA ADIB & $0.892\left(11.105^{* * *}\right)$ & $0.151\left(1.721^{*}\right)$ & $-0.854(-0.055)$ & $4.557[0.033]$ \\
\hline 4 & ALLIANCE DANA ALIF & $0.511\left(7.049^{* * *}\right)$ & $0.071(1.118)$ & $-0.058(-0.483)$ & $0.160[0.689]$ \\
\hline 5 & AM ASSURANCE DANA TEGUH & $0.708\left(16.844^{* * *}\right)$ & $0.546(0.134)$ & $0.061(0.830)$ & $4.364[0.037]$ \\
\hline 6 & AM BON ISLAM & $0.131\left(2.613^{* * *}\right)$ & $0.276(0.976)$ & $-0.123\left(-1.953^{*}\right)$ & $0.670[0.796]$ \\
\hline 7 & AM ISLAMIC BALANCED & $0.706\left(15.142^{* * *}\right)$ & $-0.967(-0.225)$ & $0.021(0.266)$ & 2.408 [0.121] \\
\hline 8 & AM ISLAMIC GROWTH & $0.990\left(17.935^{* * *}\right)$ & $-0.034(-0.693)$ & $0.035(0.461)$ & $0.853[0.356]$ \\
\hline 9 & AM ITTIKAL & $0.968\left(12.465^{* * *}\right)$ & $-0.086(-1.378)$ & $-0.056(-0.295)$ & $0.278[0.868]$ \\
\hline 10 & AM OASIS GLOBAL ISLAMIC EQUITY & $0.289\left(2.473^{* * *}\right)$ & $0.036(0.539)$ & $-0.220(-1.220)$ & $0.735[0.786]$ \\
\hline 11 & AMANAH SAHAM BANK SIMPANAN NASION & $0.517\left(7.202^{* * *}\right)$ & $0.064(0.927)$ & $-0.172(-1.407)$ & $1.467[0.226]$ \\
\hline 12 & AMANAH SAHAM DARUL IMAN & $0.769\left(10.830^{* * *}\right)$ & $0.793(0.178)$ & $0.090(1.270)$ & 3.500 [0.061] \\
\hline 13 & AMB DANA ARIF A MYR & $0.092(1.633)$ & $-0.056(-0.836)$ & $0.164(0.014)$ & 1.018 [0.313] \\
\hline 14 & AMB DANA YAKIN & $0.767\left(15.320^{* * *}\right)$ & $0.014(0.410)$ & $0.200(0.234)$ & $1.352[0.245]$ \\
\hline 15 & APEX DANA AL-FAIZ-I & $0.996\left(6.870^{* * *}\right)$ & $-0.079(-0.605)$ & $0.178(0.621)$ & $0.191[0.989]$ \\
\hline 16 & APEX DANA AL-SOFI-I & $0.768\left(10.386^{* * *}\right)$ & $0.268\left(3.796^{* * *}\right)$ & $-0.037(-0.378)$ & $0.138[0.906]$ \\
\hline 17 & APEX DANA ASLAH & $0.730\left(17.935^{* * *}\right)$ & $-0.034(-0.693)$ & $0.035(0.461)$ & $0.371[0.543]$ \\
\hline 18 & ASM AMANAH SAHAM PEKERJA TNB & $0.805\left(11.542^{* * *}\right)$ & $0.012(0.172)$ & $-0.126(-0.851)$ & 3.304 [0.069] \\
\hline 19 & ASM DANA AL-AIMAN & $0.661\left(13.976^{* * *}\right)$ & $-0.022(-0.358)$ & $-0.012(-0.136)$ & 0.912 [0.763] \\
\hline 20 & ASM DANA BESTARI & $0.654(12.009 * * *)$ & $-0.059(-0.903)$ & $-0.142(-1.185)$ & 1.821 [0.177] \\
\hline 21 & ASM DANA MUTIARA & $0.911\left(12.345^{* * *}\right)$ & $0.014(0.269)$ & $-0.201\left(-2.166^{* *}\right)$ & $2.772[0.096]$ \\
\hline 22 & ASM SHARIAH AGGRESSIVE & $0.726\left(10.584^{* * *}\right)$ & $0.056(0.919)$ & $-0.095(-0.682)$ & $2.348[0.125]$ \\
\hline 23 & ASM SHARIAH BALANCED & $0.474(17.424 * * *)$ & $-0.111(-1.752 *)$ & $-0.134\left(-1.744^{*}\right)$ & $2.940[0.086]$ \\
\hline 24 & ASM SHARIAH CASH MANAGEMENT & $0.066\left(3.070^{* * *}\right)$ & $-0.046(-1.393)$ & $-0.116(-2.091)$ & 0.232 [0.629] \\
\hline 25 & ASM SHARIAH GROWTH & $0.990\left(17.935^{* * *}\right)$ & $-0.034(-0.693)$ & $0.035(0.461)$ & $0.853[0.356]$ \\
\hline 26 & ASM SHARIAH INDEX & $0.856\left(23.621^{* * *}\right)$ & $-0.088\left(-3.404^{* * *}\right)$ & $0.833(0.122)$ & $0.144[0.705]$ \\
\hline 27 & ASM SHARIAH PREMIER & $0.525\left(9.367^{* * *}\right)$ & $0.038(0.855)$ & $0.074(0.737)$ & 2.834 [0.092] \\
\hline 28 & ASM SHARIAH TACTICAL & $0.675\left(12.757^{* * *}\right)$ & $0.179\left(3.279^{* * *}\right)$ & $0.069(0.790)$ & $0.182[0.670]$ \\
\hline 29 & AXA AFFIN DANA IMBANG & $0.990\left(17.935^{* * *}\right)$ & $-0.034(-0.693)$ & $0.035(0.461)$ & $0.853[0.356]$ \\
\hline 30 & BIMB DANA AL-FAKHIM & $0.020(0.406)$ & $0.070\left(2.068^{* *}\right)$ & $-0.086(-0.812$ & $0.148[0.701]$ \\
\hline 31 & BIMB DANA AL-FALAH & $0.757\left(7.549^{* * *}\right)$ & $0.076(1.302)$ & $-0.082(-0.576)$ & $0.246[0.620]$ \\
\hline 32 & BIMB DANA AL-MUNSIF & $0.576\left(7.467^{* * *}\right)$ & $0.158\left(2.549^{* *}\right)$ & $-0.115(-0.931)$ & $0.628[0.428]$ \\
\hline 33 & BIMB I GROWTH & $0.729\left(10.102^{* * *}\right)$ & $0.054(0.549)$ & $-0.258\left(-2.424^{* *}\right)$ & $0.886[0.347]$ \\
\hline 34 & CIMB ISLAMIC BALANCED & $0.697\left(13.061^{* * *}\right)$ & $0.082(1.446)$ & $-0.038(-0.397)$ & $0.403[0.841]$ \\
\hline 35 & CIMB ISLAMIC BALANCED GROWTH & $0.618\left(4.635^{* * *}\right)$ & $-0.053(-0.304)$ & $-0.144(-1.102)$ & $1.840[0.175]$ \\
\hline 36 & CIMB ISLAMIC DALI EQUITY GROWTH & $0.348\left(1.796^{*}\right)$ & $-0.387(-1.524)$ & $0.389(1.360)$ & 0.409 [0.949] \\
\hline 37 & CIMB ISLAMIC ENHANCED SUKUK & $-0.053(-0.618)$ & $-0.038(-0.388)$ & $0.244\left(2.00^{* *}\right)$ & $0.217[0.883]$ \\
\hline 38 & CIMB ISLAMIC EQUITY AGGRESSIVE & $0.218(1.556)$ & $-1.151(-0.559)$ & $0.397(1.347)$ & $0.759[0.783]$ \\
\hline 39 & CIMB ISLAMIC SMALL CAP & $0.160(0.903)$ & $0.014(-0.062)$ & $0.322(0.869)$ & $1.454[0.228]$ \\
\hline 40 & CIMB ISLAMIC SUKUK & $0.659(0.216)$ & $-0.044(-1.395)$ & $0.033(0.987)$ & $0.471[0.493]$ \\
\hline 41 & DANA EKUITI PRIMA & $0.315(1.589)$ & $-0.057(-0.230)$ & $0.366(1.376)$ & $0.319[0.572]$ \\
\hline 42 & DANA ISLAMIAH AFFIN & $0.110(0.825)$ & $-0.073(-0.462)$ & $0.185(1.039)$ & $0.326[0.568]$ \\
\hline 43 & DANA MAKMUR PHEIM & $0.200(1.632)$ & $-0.023(-0.182)$ & $0.149(0.905)$ & $0.171[0.679]$ \\
\hline 44 & DANA PENDAPATAN PRIMA & $0.064(1.258)$ & $0.433(0.084)$ & $-0.696(-0.097)$ & $0.305[0.581]$ \\
\hline 45 & DANA RESTU & $0.212(1.443)$ & $-0.149(-0.771)$ & $0.370(1.376)$ & $0.923[0.337]$ \\
\hline 46 & DANA SEJATI & $0.091\left(1.826^{*}\right)$ & $-0.084(-1.526)$ & $0.744(0.135)$ & $6.285[0.012]$ \\
\hline 47 & EASTSPRING INVESTMENTS DANA AL-ILHA] & $0.200(1.140)$ & $-0.161(-0.577)$ & $0.477(1.420)$ & $1.142[0.285]$ \\
\hline 48 & EASTSPRING INVESTMENTS DANA AL-ISLAF & $0.058(1.503)$ & $-0.054(-0.574)$ & $0.132(1.469)$ & $0.807[0.776]$ \\
\hline 49 & EASTSPRING INVESTMENTS DANA DINAMIK & $0.148(1.065)$ & $-0.067(-0.346)$ & $0.252(1.107)$ & $1.355[0.244]$ \\
\hline 50 & EASTSPRING INVESTMENTS DANA WAFI & $0.048(0.854)$ & $-0.115(-1.933 *)$ & $0.011(0.128)$ & 0.669 [0.413] \\
\hline 51 & HLA VENTURE DANA PUTRA & $0.189(1.352)$ & $0.669(0.046)$ & $0.154(0.962)$ & $0.547[0.459]$ \\
\hline 52 & HONG LEONG DANA MAA'ROF & $0.122(0.083)$ & $-0.034(-0.194)$ & $0.443(1.754 *)$ & $0.133[0.908]$ \\
\hline
\end{tabular}


(Continued)

\begin{tabular}{|c|c|c|c|c|c|}
\hline & Unit Trust Fund & bi & si & hi & GMM \\
\hline 53 & HWANG AIIMAN GROWTH & $0.178(1.237)$ & $-0.264(-1.166)$ & $0.929\left(3.226^{* * *}\right)$ & $0.676[0.795]$ \\
\hline 54 & HWANG AIIMAN INCOME PLUS & $0.609\left(7.718^{* * *}\right)$ & $0.036(0.616)$ & $0.011(0.075)$ & $1.904[0.168]$ \\
\hline 55 & KENANGA ISLAMIC & $1.597\left(7.893^{* * *}\right)$ & $0.303\left(2.925^{* * *}\right)$ & $0.173(0.446)$ & $0.696[0.934]$ \\
\hline 56 & KENANGA ISLAMIC BALANCED & $0.868\left(14.902^{* * *}\right)$ & $0.102(1.689 *)$ & $0.079(0.392)$ & $0.410[0.522]$ \\
\hline 57 & KENANGA OA INV-KENANGA BON ISLAM & $0.091\left(3.745^{* * *}\right)$ & $-0.032\left(-1.631^{* * *}\right)$ & $-0.039(-0.733)$ & $4.927[0.026]$ \\
\hline 58 & KENANGA OA INV-KENANGA EKUITI ISLAM & $1.142\left(14.461^{* * *}\right)$ & $-0.142(-0.687)$ & $-0.130(-0.484)$ & $0.708[0.400]$ \\
\hline 59 & KENANGA OA INV-KENANGA SHARIAH BAI & $0.533\left(19.210^{* * *}\right)$ & $-0.679(-0.235)$ & $0.037(0.917)$ & $4.469[0.035]$ \\
\hline 60 & KENANGA OA INV-KENANGA SHARIAH GRC & $0.886(9.004 * * *)$ & $0.246\left(2.568^{* * *}\right)$ & $0.036(0.160)$ & $0.143[0.706]$ \\
\hline 61 & KENANGA SYARIAH GROWTH & $0.897(14.359 * * *)$ & $0.078(1.124)$ & $-0.043(-0.433)$ & $3.553[0.059]$ \\
\hline 62 & LIBRA AMANAH SAHAM WANITA & $0.848\left(13.483^{* * *}\right)$ & $0.054(1.381)$ & $-0.722(-0.519)$ & $1.051[0.305]$ \\
\hline 63 & LIBRA ASNITA BOND & $0.061\left(2.609^{* * *}\right)$ & $0.062\left(3.258^{* * *}\right)$ & $-0.110\left(-1.923^{*}\right)$ & $0.347[0.556]$ \\
\hline 64 & LIBRA SYARIAH EXTRA & $0.776\left(11.437^{* * *}\right)$ & $0.027(0.546)$ & $-0.294\left(-2.112^{* *}\right)$ & $3.399[0.065]$ \\
\hline 65 & MAAKL AL-FAID & $0.923\left(18.295^{* * *}\right)$ & $-0.767(-0.107)$ & $0.062(0.585)$ & $0.798[0.778]$ \\
\hline 66 & MAAKL AL-FAUZAN & $0.533\left(7.069^{* * *}\right)$ & $-0.093(1.722 *)$ & $0.056(0.555)$ & $3.666[0.056]$ \\
\hline 67 & MAAKL AL-UMRAN & $0.609\left(8.225^{* * *}\right)$ & $-0.071(1.799 *)$ & $-1.158\left(-1.645^{*}\right)$ & $0.209[0.885]$ \\
\hline 68 & MAAKL AS-SAAD & $-0.093(-1.283)$ & $0.010(0.376)$ & $-0.469(-0.055)$ & $0.989[0.757]$ \\
\hline 69 & MAAKL SYARIAH INDEX & $0.961\left(20.172^{* * *}\right)$ & $-0.165(-1.739 *)$ & $-0.116(-1.136)$ & $0.968[0.756]$ \\
\hline 70 & MANULIFE DANA EKUITI DINAMIK & $0.928(14.489 * * *)$ & $0.183(2.228 * *)$ & $-0.292(-1.752 *)$ & $2.035[0.154]$ \\
\hline 71 & MIDF AMANAH DYNAMIC & $0.687\left(12.427^{* * *}\right)$ & $-0.126(2.997 * * *)$ & $-0.117(-0.689)$ & $0.141[0.999]$ \\
\hline 72 & MIDF AMANAH GROWTH & $0.690\left(8.256^{* * *}\right)$ & $0.011(0.135)$ & $-0.028(-0.194)$ & $0.345[0.557]$ \\
\hline 73 & MIDF AMANAH ISLAMIC & $0.757\left(11.921^{* * *}\right)$ & $0.034(0.751)$ & $-0.012(-0.105)$ & $1.597[0.206]$ \\
\hline 74 & MIDF AMANAH MONEY MARKET & $0.028(1.338)$ & $0.039(1.236)$ & $-0.666(-0.167)$ & $0.659[0.797]$ \\
\hline 75 & MIDF AMANAH STRATEGIC & $0.620\left(11.817^{* * *}\right)$ & $0.176\left(4.310^{* * *}\right)$ & $-0.126(-0.011)$ & $4.841[0.028]$ \\
\hline 76 & PACIFIC DANA AMAN & $0.827\left(8.700^{* * *}\right)$ & $0.119(1.838 * *)$ & $-0.296(-0.877)$ & $0.276[0.599]$ \\
\hline 77 & PACIFIC DANA MURNI & $0.087\left(3.229^{* * *}\right)$ & $-0.033(-1.577)$ & $-0.125(-1.319)$ & $0.190[0.965]$ \\
\hline 78 & PB ISLAMIC BOND & $0.094\left(2.715^{* * *}\right)$ & $-0.977(-0.151)$ & $-0.125\left(-1.653^{*}\right)$ & $0.296[0.863]$ \\
\hline 79 & PB ISLAMIC EQUITY & $1.015\left(5.444^{* * *}\right)$ & $0.199(1.287)$ & $0.118(0.791)$ & $0.521[0.470]$ \\
\hline 80 & PRULINK DANA AMAN & $0.086\left(3.105^{* * *}\right)$ & $-0.244(-0.109)$ & $-0.024(-0.424)$ & $4.706[0.030]$ \\
\hline 81 & PRULINK DANA UNGGUL & $0.937\left(12.441^{* * *}\right)$ & $0.105\left(2.011^{* *}\right)$ & $0.025(0.217)$ & $0.147[0.904]$ \\
\hline 82 & PRULINK DANA URUS & $0.702\left(12.428^{* * *}\right)$ & $0.073(1.739 *)$ & $0.782(0.098)$ & $0.104[0.919]$ \\
\hline 83 & PUBLIC ISLAMIC BOND & $0.028(0.407)$ & $0.068(1.940 *)$ & $-0.096(-1.181)$ & $0.244[1.876]$ \\
\hline 84 & PUBLIC ISLAMIC DIVIDEND & $0.896\left(18.716^{* * *}\right)$ & $0.039(0.718)$ & $-0.051(-0.675)$ & $0.176[0.895]$ \\
\hline 85 & PUBLIC ISLAMIC EQUITY & $1.099\left(10.398^{* * *}\right)$ & $-0.082(-0.536)$ & $-0.272(-1.699 *)$ & $2.141[0.143]$ \\
\hline 86 & PUBLIC ISLAMIC MIXED ASSET & $0.666\left(10.585^{* * *}\right)$ & $0.020(0.359)$ & $0.032(0.352)$ & $0.981[0.322]$ \\
\hline 87 & PUBLIC ISLAMIC OPPORTUNITIES & $1.021\left(9.825^{* * *}\right)$ & $0.490(5.095)$ & $0.093(0.394)$ & $0.299[0.584]$ \\
\hline 88 & PUBLIC ITTIKAL & $1.046\left(9.656^{* * *}\right)$ & $-0.097(-0.836)$ & $-0.251(-1.558)$ & $1.714[0.191]$ \\
\hline 89 & RHB-OSK DANA ISLAM & $1.128(15.639 * * *)$ & $0.231\left(3.706^{* * *}\right)$ & $-0.068(-0.406)$ & $2.868[0.090]$ \\
\hline 90 & RHB-OSK ISLAMIC BOND & $0.077(1.630)$ & $-0.782(-0.197)$ & $-0.096(-0.974)$ & $0.420[0.948]$ \\
\hline 91 & RHB-OSK ISLAMIC GROWTH & $0.986(13.732 * * *)$ & $0.038(0.539)$ & $0.057(0.536)$ & $0.728[0.932]$ \\
\hline 92 & RHB-OSK MUDHARABAH & $0.637\left(13.515^{* * *}\right)$ & $0.122(2.377)$ & $-0.064(-0.677)$ & $0.553[0.814]$ \\
\hline 93 & TA DANA OPTIMIX & $0.833\left(8.421^{* * *}\right)$ & $0.285\left(2.250^{* *}\right)$ & $-0.186(-1.170)$ & $0.265[0.607]$ \\
\hline 94 & TA ISLAMIC & $0.857(12.724 * * *)$ & $0.064(0.368)$ & $-0.307(-1.581)$ & $0.636[0.801]$ \\
\hline 95 & TABUNG AMANAH SAHAM KEDAH & $0.505\left(3.965^{* * *}\right)$ & $0.358\left(3.378^{* * *}\right)$ & $-0.151(-0.414)$ & $1.398[0.237]$ \\
\hline 96 & ZURICH DANA MAS YAKIN & $0.582\left(14.590^{* * *}\right)$ & $0.553(0.117)$ & $0.110(1.921 *)$ & $1.671[0.196]$ \\
\hline 97 & ZURICH DANA SERI MULIA & $-0.759(-0.101)$ & $0.054\left(1.820^{*}\right)$ & $-0.033(-0.384)$ & $0.725[0.932]$ \\
\hline 98 & AMB DANA IKHLAS & $0.783(0.0489)$ & $0.228(1.540)$ & $0.135(0.651)$ & $0.145[0.704]$ \\
\hline 99 & CIMB ISLAMIC ASIA PACIFIC EQUITY & $0.075(-0.326)$ & $0.081(0.460)$ & $0.048(0.154)$ & $0.137[0.712]$ \\
\hline 100 & CIMB ISLAMIC DALI EQUITY & $1.073\left(16.371^{* * *}\right)$ & $0.023(0.433)$ & $-0.339\left(-3.021^{* * *}\right)$ & $0.257[0.873]$ \\
\hline 101 & HONG LEONG DANA MAKMUR & $0.863\left(9.431^{* * *}\right)$ & $0.262\left(4.217^{* * *}\right)$ & $-0.046(-0.186)$ & $0.902[0.342]$ \\
\hline 102 & MIDF AMANAH SHARIAH MONEY MARKET & $0.028(1.338)$ & $-0.034(-0.693)$ & $0.035(0.461)$ & $0.853[0.356]$ \\
\hline 103 & ZURICH DANA MAS MAJU & $0.798\left(13.078^{* * *}\right)$ & $-0.019(-0.426)$ & $0.135(1.338)$ & $2.434[0.119]$ \\
\hline
\end{tabular}


Table B.2: Summary of Market, SMB and HML betas for the Pre-Lehman Bros. sub-period.

\begin{tabular}{|c|c|c|c|c|c|}
\hline & Mean & Max & Min & Sig. Positive & Sig. Negative \\
\hline bi & 0.568 & 1.597 & -0.759 & 100 & 3 \\
\hline si & 0.008 & 0.810 & -1.151 & 57 & 46 \\
\hline hi & -0.014 & 0.929 & -1.158 & 47 & 56 \\
\hline
\end{tabular}

Notes: This table presents the results of testing the FF model in the system of regressions (3), (4), (5), and (6). The sample is monthly return data extending from May 2006 to August 2008. GMM is Sargan or J test statistic of overidentifying restrictions. Standard Errors computed from a heteroscedastic-consistent matrix (Robust-White). The associated t-statistic is in parentheses ( ). The associated p-value is in square brackets [ ]. ${ }^{* * *},{ }^{* *},{ }^{*}$ indicates significant at 1 percent level, 5 percent level, and 10 percent level, respectively.

\section{Appendix C}

Table $\mathrm{C}$ below reports average monthly returns based on trading strategies for portfolios of Islamic stocks which are grouped according to size (large and small capitalization) and valuation (value and growth stocks).

The trading strategies are based on buying small cap and selling large cap stocks as well as buying value and selling growth stocks. These strategies are further sorted based on portfolios of SMB (small minus big capitalization stocks) and HML (high minus low, or value minus growth) stocks for the full period of the study (from May 2006 to April 2011), pre-crisis period (May 2006 to August 2008) and post-crisis period (September 2008 to April 2011)

The monthly returns based on trading strategies for the portfolios are calculated as below:-

$$
\begin{aligned}
& \text { Trading strategy } S M B=\left(\frac{R S V t+R S G t}{2}\right) X\left(\frac{R L V t+R L G t}{2}\right) \\
& \text { Trading strategy } H M L=\left(\frac{R S V t+R M V t+R L V t}{3}\right) X\left(\frac{R S G t+R M G t+R L V t}{3}\right)
\end{aligned}
$$

The returns for both SMB and HML repeated to calculate monthly returns for the full period, pre-crisis period and postcrisis period.

Table C: Returns from Trading Strategies

\begin{tabular}{llrrrrrrr}
\hline & & Mean & \multicolumn{1}{c}{ SD } & \multicolumn{1}{c}{ T-statistic } & \multicolumn{1}{l}{ Skewness } & \multicolumn{1}{l}{ Kurtosis } & \multicolumn{1}{c}{ AR $(1)$} & ARCH(1) \\
\hline Full period & SMB & 0.1412 & 4.3173 & 0.1512 & 0.1056 & 0.1476 & $0.0267(0.8421)$ & $0.1445(0.6991)$ \\
& HML & 0.2612 & 2.8116 & 0.2622 & 1.6321 & 5.5229 & {$[-0.048](0.7178)$} & $0.0001(0.9909)$ \\
\hline Pre crisis period & SMB & 0.0245 & 5.0869 & 0.0171 & 0.3669 & -0.1343 & {$[-0.010](0.9632)$} & $0.0327(0.8506)$ \\
& HML & 0.4919 & 2.7099 & 0.3421 & 0.8166 & 1.4184 & $0.1093(0.5960)$ & $1.3996(0.2311)$ \\
\hline Post crisis period & SMB & 0.2396 & 3.6261 & 0.1932 & -0.4125 & 0.3031 & $0.0858(0.6493)$ & $0.8801(0.3390)$ \\
& HML & 0.0666 & 2.9232 & 0.0477 & 2.2918 & 9.4770 & {$[-0.173](0.3578)$} & $0.1933(0.6502)$ \\
\hline
\end{tabular}

